\title{
Erratum
}

\section{Molecular Cloning of the Genes for Xylan Degradation of Bacillus pumilus and Their Expression in Escherichia coli}

Mol Gen Genet (1983) 192:335-341

Watanalai Panbangred, Tetsuya Kondo, Seiji Negoro, Atsuhiko Shinmyo, and Hirosuke Okada Department of Fermentation Technology, Osaka University, Yamada-oka Suita-shi, Osaka 565, Japan

One page 337, there is a mistake in the text to Table 1.

The text should read:

Table 1. Activities of xylan-hydrolyzing enzymes in an E. coli transformant

\begin{tabular}{lll}
\hline Strains & $\begin{array}{l}\beta \text {-Xylosidase } \\
\text { (m units/mg } \\
\text { protein) }\end{array}$ & $\begin{array}{l}\text { Xylanase } \\
\text { (m units } / \mathrm{mg} \\
\text { protein) }\end{array}$ \\
\hline B. pumilus IPO & 16.7 & 35.5 \\
E. coli C600 & 0 & 0 \\
E. coli C600 (pOXN29) & 3.3 & 2.3 \\
\hline
\end{tabular}

B. pumilus cells were grown in L-broth containing $1 \%$ xylose, which was the best inducer for $\beta$-xylosidase and xylanase, for $40 \mathrm{~h}$ at $30^{\circ} \mathrm{C} . \beta$-xylosidase in the cell extract and xylanase in the culture medium were expressed per mg cell protein. $E$. coli cells were grown in L-broth supplemented with $0.1 \%$ xylose and $15 \mu \mathrm{g} / \mathrm{ml}$ tetracycline overnight at $37^{\circ} \mathrm{C}$, and both activities in the cell extract were measured. E. coli synthesized both enzymes constitutively (data not shown) 